Dorian-Laurentiu Florea,

Ph.D., Anahuac University Mexico, Mexico

Claudiu-Catalin Munteanu,

Ph.D., The Romanian Academy, Romania

Dora-Carmen Galvez Cruz,

Ph.D., Anahuac University Mexico, Mexico

Gabriela Capatina,

Ph.D., The Bucharest University of Economic Studies, Romania

\title{
THE IMPACT OF PRODUCT CATEGORY LIFECYCLE AND MARKETING CAPABILITIES ON NEW PRODUCT PERFORMANCE: THE MEDIATING ROLE OF MARKETING PROGRAM PLANNING AND LAUNCH PROFICIENCY
}

Abstract. Theory underlines the role of new product development for company survival and success. However, the success rates of new products launches are always at underwhelming levels. Practical wisdom shows that new product performance is the outcome of both controllable, internal factors and external, uncontrollable factors. The authors contrast the role of product category lifecycle as an external factor and of marketing capabilities as an internal factor, to find the balance between these two determinants. To the best of our knowledge, this is the first study to compare the impact of both types of factors on launch proficiency and further product growth. We apply PLS-SEM on a sample of 213 Mexican firms to test a theoretical model grounded on resource-advantage theory and strategic choice theory. Results show that both determinants are significant, but marketing capabilities exert a much stronger influence on new product performance. The relationship between marketing capabilities and unique product performance is mediated by marketing program planning. In contrast, the relationship between product category lifecycle and new product performance is mediated by launch proficiency. In this context, marketing program planning efficiency represents the mid-term and long-term quality of strategic marketing. At the same time, the overall launch proficiency reflects the short-term ability of the company to launch new products. From the perspective of strategic choice theory, the results of our study reinforce the importance of a successful launch for the short-term and mid-term new product performance. Besides, our empirical research finds that product category lifecycle strengthens the positive relationship between marketing program planning and unique product performance. This makes marketing program planning more critical for new product performance as the product category matures. From a managerial standpoint, our findings dismiss the uncontrollable market forces as the main reason for new product failures. We show that new product failures are most often caused by the marketing manager's inability to devise an appropriate marketing plan. The paper also contributes to the literature of resource-advantage theory by providing compelling evidence regarding the foremost importance of marketing capabilities for new product success. Our findings also emphasize the essential role of launch proficiency in further product success, as it is difficult to recover from an early product failure. In practical terms, managers are advised not to postpone new product launches under the «bad timing» argument.

Keywords: launch proficiency, marketing capabilities, marketing program planning, new product performance, product lifecycle.

Introduction. Launching a new product is commonly seen as a critical moment in the existence of every firm, which determines its survival and success (Cooper, 2011; Slater \& Narver, 1994). The high rate of new product failures consistently reported in previous works (Castellion \& Markham, 2013) justifies the central attention given to this topic by both researchers and practitioners in the past decades. The antecedents of new product performance have been found both internally and externally (see MontoyaWeiss \& Calantone, 1994, for a comprehensive review). However, the balance between the two has received little attention.

Cite as: Florea, D. L., Munteanu, C. C., \& Capatina, G. (2020). The Impact of Product Category Lifecycle and Marketing Capabilities on New Product Performance: the Mediating Role of Marketing Program Planning and Launch Proficiency. Marketing and Management of Innovations, 1, 63-85. http://doi.org/10.21272/mmi.2020.1-05 
D. L. Florea, C. C. Munteanu, G. Capatina. The Impact of Product Category Lifecycle and Marketing Capabilities on New Product Performance: the Mediating Role of Marketing Program Planning and Launch Proficiency

However, previous studies either focus exclusively on internal drivers (Langerak et al., 2004) or external drivers (Gatignon \& Xuereb, 1997), leaving the mix between the two virtually unaddressed. Nonetheless, in actual product launches, new product performance is simultaneously influenced by both internal and external factors (Muller-Stewens \& Moller, 2017). As a consequence, filling this gap would provide managers with the necessary tools to more accurately assess the likelihood of a successful new product and to device strategies that improve its chances of success.

This study attempts to bring three contributions to marketing knowledge. Firstly, we contrast significant internal and external determinants of new product performance, on the one hand, and launch activities, on the other hand, against mid-term and long-term planning. In doing so, we synergistically employ resource-advantage theory and strategic choice theory. Secondly, depending on the results, we either explain the low rate of new product success or an argument against blaming uncontrollable forces of the macro-environment for new product failure. Thirdly, this study aims to approach the classical concept of the product lifecycle, an idea which has been scantly analyzed in recent scientific papers.

In the following section, we introduce our proposed conceptual model, together with the theoretical background that supports it and the subsequent hypotheses. The next section comprises the empirical study - including the methodology used in data collection - and the construct measurement and validation. The third section presents the results of the investigation. In chapter four, results are discussed concerning the existing literature, and managerial implications are assessed. In the final section, we identify research limitations, propose future research directions and formulate the main conclusions, while addressing the considered literature gap.

Literature Review. The effects of internal and external determinants of new product performance need to be evaluated simultaneously to fill the literature gap regarding launching new products. This approach allows us to compare the relative influence of internal and external determinants and thus to comprehend better the extent to which new product performance depends on the firm and uncontrollable factors, respectively. Following the path of previous studies (Cacciolatti \& Lee, 2016), we align to resourceadvantage theory (Hunt \& Morgan, 1996; 1997) by considering marketing capabilities an internal factor, for its capacity to reveal the level of professionalism of a company's marketing personnel and processes. The resource-advantage theory regards organizational skills as intangible resources that are not scarce (Hunt \& Morgan, 1997). According to this perspective, organizational capabilities can be replicated without diminishing the capabilities of the benchmark organization.

Consequently, marketing capabilities are not limited to a particular company or market, thus being completely controllable. Marketing capabilities represent valuable, improvable, and intangible sources of competitive advantage (Vorhies \& Morgan, 2005) that a firm develops in time through its personnel, organizational processes, experience, and know-how. Literature highlights two distinct conceptual approaches to obtaining a competitive advantage. The first approach focused on marketing-related activities - such as product, pricing, distribution, communication, selling, planning, implementation (Murray et al., 2011; Morgan, Vorhies \& Mason, 2009). The second approach concentrates on transversal competencies applied to market - such as accountability, innovativeness, teamwork, and leadership (Verhoef et al., 2011; Rust et al., 2004).

The external determinants of new product performance are best represented through the product category lifecycle, due to its uncontrollable and unpredictable traits (Calantone et al., 2010). In terms of the product category lifecycle, the arguments of managers or powerful internal groups to postpone or cancel new product launches come most often at the wrong moment in time. Thus, the inclusion of this external variable builds upon strategic choice theory (Child, 1997) is aiming to prove that this argument is meant to serve personal or group interests that oppose to the organizational interests (Ploscaru et al., 2014). Specifically, product or marketing managers can advocate against a new product launch to avoid the risk of potential failure or even to conceal the lack of marketing capabilities that they are responsible 
for (Zacharias et al., 2017). By demonstrating that the product category lifecycle has a minor effect on new product performance in comparison with marketing capabilities, we seek to dismiss this one-sided argument and to provide empirical evidence for the prevailing importance of marketing capabilities. Despite predicting a relatively lower impact of the product category lifecycle on new product performance, we expect a significant and positive effect. According to resource-advantage theory, organizational knowledge is largely heterogeneous between firms, but is significantly improvable through organizational learning, although it never reaches the level of full relevant experience (Hunt \& Morgan, 1997). The process of organizational learning is likely to occur gradually throughout the product category lifecycle and may positively impact routine marketing activities and launch proficiency.

Previous research has discovered that industry lifecycle moderates the relationship between firm entry size and firm survival (Agarwal \& Audretsch, 2001), which represents a particular case of our study, where the new product is the firm's first new product. Jain's (2001) findings prove that poor launch timing is among the primary causes of new product failure, caused by consumers' lack of interest. By including the product category lifecycle and marketing capabilities to our model, we answer to a modified version of O'Cass and Heirati's (2015) question: «To what extent do marketing capabilities enhance and sustain the performance of a new product for each phase of the product's lifecycle? »

The impact of marketing capabilities and product category lifecycle on new product performance can be noticed both immediately, in the way launch activities are performed, and later, in the on-going marketing program planning, for which two mediators must be considered. Considering Conant \& White (1999), the marketing program planning could be defined as «the on-going managerial process of assessing internal marketing competencies and external environmental trends, segmenting the marketplace, and then formally configuring, efficiently implementing, and systematically evaluating marketing mix strategies to achieve organizational objectives». Conan \& White (1999) identify four elements worth measuring in marketing program planning, namely formal planning, strategic clarity, the extent of segmentation, and rapid market response. Through developing all these aspects, firms increase the chances of creating and launching successful new products. Launch proficiency is the ability to make decisions and perform launch-related activities, namely market testing, launch budgeting, strategy and tactics (Langerak et al., 2004). By including these two variables, we want to compare the impact of the launch moment and further development on new product performance. The stronger the link between launch proficiency and unique product performance, the higher the dependence on the initial conditions, from an internal point of view.

Despite the lack of agreement on the definition and the dimensions of new product performance, we define new product performance as "the management's perception regarding new product success», following Slater and Narver's (1994) view. This approach allows us to work with subjectively reported measures, but also with isolated self-evaluations rather than with relative comparisons with competitors' new products (Gatignon \& Xuereb, 1997). Further product performance evaluation was made on a shortterm or medium-term, given the characteristics of the sample used in the study. However, the long-term performance was preferred in previous studies (Green et al., 1995). All hypotheses are formulated and tested while controlling for firm size and market.

Companies can benefit from industry experience (Cassar, 2014). These benefits multiply and expand as the product category matures, due to the increased number of successful and failed competitors, the wide variety of already tested marketing strategies, and the longer time for industry learning to be reconfirmed. Thus, firms can improve their marketing program planning based on previous successes and failures in the product category (Zahra et al., 2015). Companies can also benefit from their own experience. As the product category matures, firms will likely have had more years competing in that category and a significant experience accumulated from previous product launches. This experience together with the knowledge sourced from suppliers, customers, and competitors, should provide valuable insights 
D. L. Florea, C. C. Munteanu, G. Capatina. The Impact of Product Category Lifecycle and Marketing Capabilities on New Product Performance: the Mediating Role of Marketing Program Planning and Launch Proficiency

regarding the most successful marketing strategies and tactics in the respective product category (Schoenherr \& Swink, 2015). In time, the organizations that pay attention to these aspects develop strong knowledge regarding both successful and inadvisable strategies (Markides \& Sosa, 2013). Consequently, we hypothesize:

$\mathrm{H} 1$ : Product category lifecycle positively affects marketing program planning.

The odds of success for a new product launch should increase as the category matures, due to lower uncertainty, a higher product category penetration rate, and a higher rate of organizational learning from previous starts in the industry (Mu \& Di Benedetto, 2011). In a mature product category, consumer behaviour is better understood by marketers, which makes the evolution of consumption patterns more foreseeable. The company's prior experience also favours a higher brand equity and easier access to capital and distribution channels, which further lead to higher performance levels. Moreover, the product category lifecycle impacts new product performance through the interplay between strategic orientation and market growth, which enhances performance in high-growth markets (Gatignon \& Xuereb, 1997). Considering these aspects, firms could benefit from postponing launches to a later moment in the category lifecycle. Contrariwise, Su and Rao (2011) advise for a rapid launch of the expected performance of the new product is high. In this context, launch timing becomes a function of the balance between realistic expectations and wishful thinking. New product performance also depends on the target market potential (O'Cass \& Heirati, 2015). As a result, new products are more successful when launched in a high-potential phase. These findings are likely to be category-dependent, as shown by Green et al. (1995).

While in some product categories an early entry leads to a better performance of the new product, in other product categories a later entry is desirable. Although the relationship between market entry and unique product performance may seem non-linear, due to the natural performance decrease in the decline phase of the category lifecycle, the low number of product launches in the decline phase makes it almost irrelevant. Nonetheless, this relationship is still a controversial topic in marketing literature due to several downsides like inconsistent indicators used to measure new product performance and the endurance of the first entrants' advantage in the marketplace (Lieberman \& Montgomery, 2013), but also due to contradictory views presented in technology, organizational, and economic studies (Agarwal et al., 2002). Despite the inconsistent findings, we rely on industry-level learning to hypothesize:

$\mathrm{H} 2$ : Product category lifecycle positively affects new product performance.

Marketing program planning is critical in achieving and sustaining competitive advantage for new products (Varadarajan, 2010). Marketing program planning implies trade-offs, negotiation and compromise to identify the best methods for operationalizing a defined marketing strategy (Morgan, 2012). For this reason, new product performance depends more on the actual implementation of marketing actions rather than on general policies (Ketchen \& Hult, 2011). The relationship between strategic planning and new product performance is inconclusive, being positive in a range of studies (Dibrell et al., 2014; Conant \& White, 1999) and negative or even non-significant in other studies (Rue \& Ibrahim, 1998; Lyles et al., 1993). Schwenk and Shrader (1993) believe these contradictory results are caused by the different measurement of new product performance, typically focused on financial measures. Song et al. (2011) find a dual role in strategic planning: it enhances performance, but it harms new product development projects due to its rigidity and lack of improvisation opportunities. A meta-analysis of the topic (Brinckmann et al., 2010) finds that marketing product planning enhances new product performance, although the firm's characteristics can seriously alter the strength of this relationship. Therefore, we hypothesize:

$\mathrm{H} 3$ : Marketing program planning positively affects new product performance.

Considering $\mathrm{H} 1, \mathrm{H} 2$ and $\mathrm{H} 3$, we expect that the product category lifecycle affects new product performance through the mediating role of marketing program planning. In later stages of the product lifecycle, firms usually understand the marketplace better and acknowledge which marketing activities are successful or not. Also, companies tend to comprehend the existing consumer segments better and to 
formulate better their marketing plans, which increases the performance of their product portfolio (Lieberman \& Montgomery, 2013). Therefore, we expect that:

Ha: Marketing program planning mediates the relationship between product category lifecycle and new product performance.

In the initial stages of the product category lifecycle, companies experiment with different product concepts and improve product design (Reid, Roberts \& Moore, 2015). Companies also usually use relatively unrefined manufacturing processes and market the new product by using various exploratory strategies that ultimately lead to a high launch uncertainty (Agarwal \& Audretsch, 2001). In mature and declining product categories, products are more homogeneous, and the manufacturing process is advanced. At this point, implicit standards arise inside the industry, leaving less strategic choices, but bringing more strategic clarity in the launch process (Vickery et al., 2016). Hence, firms can benefit from the industry's experience in launch strategies (Cavusgil et al., 2011). Despite being rather singular, nonreplicable events, product launches become increasingly successful as firms learn from consumers' reactions to previous starts in the same product category (Schoenherr \& Swink, 2015). In addition to this industry learning effect, new product launches are more difficult in the early stages of the category lifecycle. For instance, firms must carefully adapt their go-to-market strategies for first versus majority market in the case of radical innovations, while incremental changes do not require such adaptation (Schuhmacher et al., 2018).

Successful launches result from the interplay between marketing and technological capabilities (Kim et al., 2016). While marketing capabilities should be mostly independent of the category lifecycle, technical skills display complex behaviour. On the one hand, technological uncertainty diminishes as the product category matures (Suarez et al., 2015), providing clear technological solutions that can be accepted on the market. On the other hand, technical capabilities require a combination of internal and external learning reflected in a patent portfolio and technology alliances. These two components of technical capabilities mutually reinforce each other in the early stages of the category lifecycle, but reciprocally undermine in the later lifecycle stages (Vanhaverbeke et al., 2015). These conflicting arguments open an exciting venue for research:

H4: Product category lifecycle positively affects launch proficiency.

New product performance is contingent on the firm's ability to plan and implement a successful launch. In case of a failed product launch, new product performance decreases significantly as the start loses momentum in relation with consumers and retailers, and even internal support (Mu \& Di Benedetto, 2011). Previous research generally supports the hypothesis that launch proficiency is critical for new product performance, although the relationship is strengthened by the corporate mindset (Talke \& Hultink, 2010a). Proficiency in launch tactics (Langerak et al., 2004), initial competitive positioning and media coverage (Green, Barclay \& Ryans, 1995), market research and new product launch (Song \& Parry, 1996) are connected to new product performance indicators. In particular, proficiency in using a lean launch strategy positively impacts new product performance (Calantone \& Di Benedetto, 2012).

In practice, strategic innovation is not only about creating a new product but also about changing customer behaviour by using the proper launch activities. Both internally and externally directed launch activities have a positive impact on market-related, time-related, and financial performance of new products (Kuester et al., 2012). These launch activities should address innovation diffusion barriers related not just to the target customers, but also to different stakeholders, such as suppliers, dealers, the general public and various institutions to enhance new product success. It is especially true when the launch occurs in a context of technological and market turbulence and product complexity (Talke \& Hultink, 2010b). A significant diffusion barrier is customers' rejection of the innovation, which may occur even when the new product outperforms its existing competitors (Gourville, 2006). Firms can overcome this barrier by 

Product Performance: the Mediating Role of Marketing Program Planning and Launch Proficiency

launching the new product as the default option, with an opt-out alternative that customers can actively select (Kuester et al., 2015). Given these findings, we hypothesize that:

H5: Launch proficiency positively affects new product performance.

Product category lifecycle, launch proficiency, and new product performance. Hypothesis $\mathrm{H} 2, \mathrm{H} 4$ and $\mathrm{H} 5$ lead us to expect that launch proficiency mediates the relationship between product category lifecycle and new product performance. As the category matures, firms gather more valuable insights from successful and failed product launches. As a consequence, launch proficiency increases. Hence, we hypothesize that:

$\mathrm{Hb}$ : Launch proficiency mediates the relation between product category lifecycle and new product performance.

Marketing capabilities are internal processes regarding marketing activities carried out well relative to competitors (Bingham et al., 2007). Marketing capabilities and marketing program planning are part of the job requirements for marketing managers and marketing staff. While marketing capabilities refer to the practical aspects of marketing, marketing program planning includes superior managerial traits like marketing vision, market responsiveness, and formality in strategic thinking. These excellent traits are virtually impossible to achieve at an organizational level in the absence of enough organizational capabilities (Morgan, 2012). Marketing capabilities allow firms to improve their market knowledge and learning, to perform insight-rich experiments, and to integrate a network of outsourcing marketing service providers. All these aspects combined lead to better marketing mix choices (Day, 2011).

Additionally, networking capabilities (Mu, 2014) and managerial social ties (Heirati \& O'Cass, 2015) enable firms to establish and manage auspicious relationships with a variety of marketing service providers and, thus, benefit from their expertise. Firms should not discard outsourcing as they enhance their marketing capabilities but use it as a complement to generate the maximum synergistic effect. These arguments make us propose the following hypothesis:

H6: Marketing capabilities positively relate to marketing program planning.

Despite using different operational definitions, previous studies consistently support that improving the internal capabilities of marketing departments is critical for new product success. Strategic marketing capabilities positively link to new product performance (O'Cass \& Heirati, 2015) by matching marketing and technological resources which result in product differentiation or cost advantage (Kim et al., 2016). Marketing and technical capabilities are highly complementary and serve as flexible strategic options for assuring new product success following the changing environmental forces (Moorman \& Slotegraaf, 1999). Marketing capabilities drive customer-related performance for new products, both alone and in complementarity with innovation capabilities (Ngo \& O'Cass, 2012) and market orientation (Najafi-Tavani et al., 2016). Marketing capabilities are essential assets not only in the commercialization phase but also for new product development (Mu, 2015). Marketing capabilities are also positively linked to organization performance (Cacciolatti \& Lee, 2016; Theodosiou et al., 2012), which is a known consequence of new product performance (Langerak et al., 2004). Overall, scholars pay much attention to the complementary role of marketing capabilities in enhancing new product performance. Thus, it is of great interest to also study the singular impact of marketing capabilities. Therefore, it is only natural to hypothesize:

$\mathrm{H7}$ : Marketing capabilities positively relate to new product performance.

In addition to $\mathrm{H} 3, \mathrm{H} 6$ and $\mathrm{H} 7$, we expect that marketing program planning mediates the positive relationship between marketing capabilities and new product performance. A firm which improves the skills of its marketing department should be able to perform better in aspects related to strategic marketing planning. These improvements in strategic marketing planning will eventually reflect in improved performance of new products. In short, we hypothesize that:

Hc: Marketing program planning mediates the relation between marketing capabilities and unique product performance. 
Developing marketing capabilities proves useful in successfully carrying out new product launches (Ngo \& O'Cass, 2012). Adaptive marketing capabilities enable strategic and tactical anticipation and the rapid reconfiguration of launch activities, which are critical aspects for a successful launch (Day, 2011). The daily experience in marketing activities contributes to successfully dealing with the challenges of new product introduction (Slater \& Narver, 1994). Nevertheless, as a rather rare event in a firm's life, launching a new product cannot be done in a trial-and-error manner, unlike most of the daily marketing decisions. Instead, a successful product introduction is always the result of well-grounded strategic and tactic marketing decisions, which require strong marketing capabilities (Gatignon et al., 2016). To enhance these marketing capabilities, companies should engage in both exploration and exploitation of new knowledge, and alternate between the two according to the external context (Vorhies et al., 2011).

Moreover, studying the content of marketing capabilities reveals the practical existence of a specific product capability that reflects the ability to develop and launch new products as a response to latent customer needs. Unless strong organizational inhibitor sets in - such as an innovation-reluctant corporate culture - marketing capabilities are likely to favour successful new product launches. Consequently, we hypothesize that:

H8: Marketing capabilities positively relates to launching proficiency.

Considering $\mathrm{H} 5, \mathrm{H} 7$ and $\mathrm{H} 8$, we can suspect that launch proficiency interposes in the relationship between marketing capabilities and new product performance. An organization with a superior level of marketing capabilities will be able to better deploy its new products to the market, which in turn will yield an excellent new product performance. Thus, we hypothesize:

Hd: Launch proficiency mediates the relationship between marketing capabilities and unique product performance.

As we hypothesized before, better marketing program planning leads to improved new product performance. We hypothesize that the intensity of this relationship varies across different stages of the product category lifecycle. Product category lifecycle is conceptually related to the order-of-entry. Order of entry has already been proven to moderate the relationship between market orientation and new product performance, in the sense that first-to-market products and late entrants achieve better performance through their quality, while early entrants by accelerating innovation speed (Rodriguez-Pinto et al., 2011). Moreover, Suarez et al. (2015) prove that along the industry lifecycle, firms enjoy windows of opportunity in which the odds of success of new products substantially increase. These opportunities can be explained in practice by a decreased impact of external factors on new product performance in favour of internal factors. In this context, organizations that engage in formal planning and have a crisp strategic view will have an almost guaranteed success (Dibrell et al., 2013).

On the contrary, outside this window of opportunity, the planning process cannot ensure new product success due to the significant influence of uncontrollable factors. Thus, we propose that:

H9: Product category lifecycle moderates the positive relationship between marketing program planning and new product performance.

A complete representation of the model regarding the impact of product category lifecycle and marketing capabilities on new product performance with all the relations between the variables described in the proposed hypotheses is depicted in Figure 1. 
D. L. Florea, C. C. Munteanu, G. Capatina. The Impact of Product Category Lifecycle and Marketing Capabilities on New Product Performance: the Mediating Role of Marketing Program Planning and Launch Proficiency

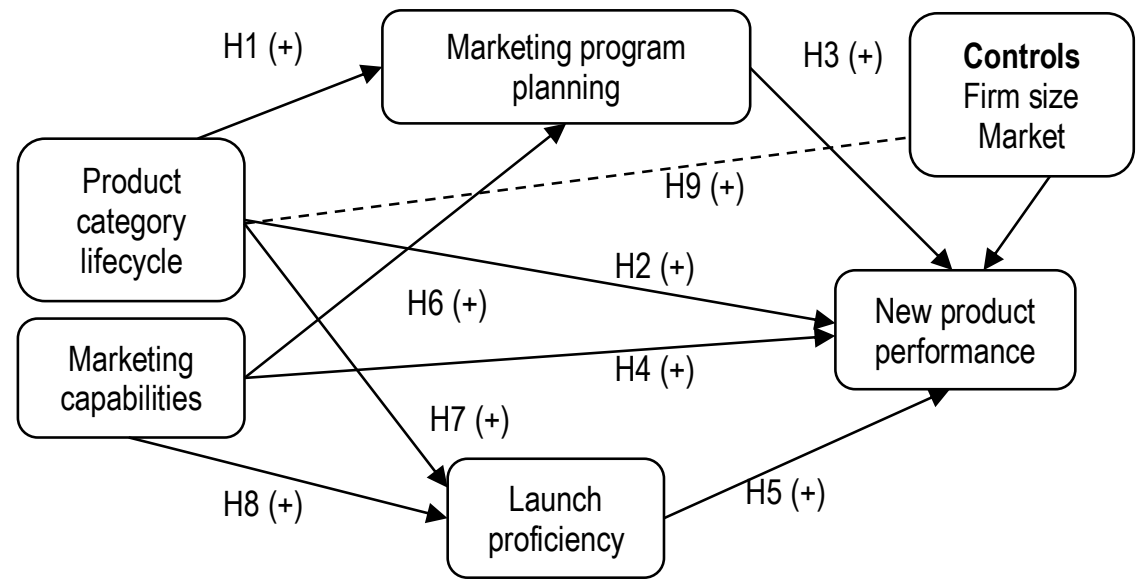

Figure 1. The proposed framework for assessing the impact of product category lifecycle and marketing capabilities on new product performance

Source: developed by the authors.

Methodology and research methods. In order to test our model, we employed an empirical study on a sample of 213 Mexican organizations that launched a new product or service in the past 24 months. We have chosen such a restrictive time frame to overcome the limitations of previous studies (Green et al., 1995) which measure long-term performance. The sample was comprised of $30 \%$ food and beverage firms, 3.8\% clothing firms, 32.9\% service firms, 13.1\% tech companies, $6.6 \%$ firms from the household industry, while $13.6 \%$ defined their industry as other. Roughly three-quarters of the firms compete primarily on a business-to-consumer market, and the rest operate in a business-to-business and/or business-togovernment market. This multi-industry sample ensures a higher degree of generalizability for our conclusions and more variance in the data. Following the best practices in marketing survey research (Hulland et al., 2018), data collection was performed using the multiple informant approach, to avoid any issues with single-source bias. This approach was preferred as objective measures of the dependent variable are difficult to obtain (Bello et al., 2016), and they would provide only a narrow perspective of new product performance (Langerak et al., 2004). For every case, the two highest-ranked knowledgeable and available individuals were interviewed. The highest-ranked of the two responded to the items related to the dependent variable, while the other individual provided information for the independent, mediator, and control variables. In cases where both respondents had the same level in the company, the two sets of items were randomly assigned. Moreover, the confidentiality policy was carefully explained before each interview to foster honest responses. The questionnaire was initially developed in English and then translated into Spanish following the back-translation approach (Atuahene-Gima, 2005), to ensure interchangeability between the two versions. The non-response rate was $42 \%$, enough to cause significant bias in our data. We used Armstrong and Overton's (1977) approach for assessing non-response bias by performing a MANOVA test to contrast responses on several subjective and objective variables from early and late respondents. Results obtained from the MANOVA test showed a non-significant Wilks' Lambda $(p=.378)$, thus proving that non-responses don't affect the overall quality of the data. To capture each of our constructs, we used both formative are reflective measures, depending on the nature of the validated scales we found appropriate in literature. This measurement combination requires two different ways of performing the validation of the measurement model. The traditional reflective measurement requires exploratory and confirmatory factor analysis. Meanwhile, the formative measure still lacks generally accepted validation tests, apart from variable weights and a multicollinearity test (Diamantopoulos \& 
D. L. Florea, C. C. Munteanu, G. Capatina. The Impact of Product Category Lifecycle and Marketing Capabilities on New Product Performance: the Mediating Role of Marketing Program Planning and Launch Proficiency

Winckhofer, 2001). Because most of our constructs are multidimensional, we considered three levels of our measurement model: the bottom level of the observed variables, the first-order constructs representing the dimensions, and the second-order constructs representing the general concept. In this approach, we carefully took into consideration the causality direction and avoided misspecification (Diamantopoulos, Riefler, \& Roth, 2008). Thus, we captured marketing capabilities, marketing program planning, launch proficiency, and new product performance as second-order formative constructs, and product category lifecycle as a first-order reflective construct.

The dimensions of marketing capabilities launch proficiency and new product performance were treated as first-order formative constructs so that every observed variable refers to a different aspect of the construct. This kind of approach makes the items not interchangeable. The four dimensions of marketing program planning were measured reflectively (Table 1).

Table 1. Measures of the investigation

\begin{tabular}{|c|c|c|c|}
\hline \multicolumn{4}{|c|}{ Product category lifecycle } \\
\hline \multicolumn{4}{|c|}{$\begin{array}{l}\text { The following blocks of questions aim to determine the stage of the product category lifecycle at the moment of your } \\
\text { last launch. Please answer on a scale of } 1-7(1=« \text { Introduction» and } 7=« \text { Decline }) \text {. }\end{array}$} \\
\hline \multirow{2}{*}{\begin{tabular}{|l|l|l|l|l}
$\mathrm{CLC} 1$ \\
$\mathrm{CLC} 2$ \\
\end{tabular}} & \multicolumn{3}{|c|}{ The market you entered with the new product was on the stage of Introduction - Decline } \\
\hline & \multicolumn{3}{|c|}{ At the time of the original product launch, its category was in the phase of Introduction - Decline } \\
\hline \multirow{2}{*}{\multicolumn{4}{|c|}{\begin{tabular}{|l|l|} 
CLC3 & Your new product competes in a group in Introduction - Decline \\
Marketing capabilities
\end{tabular}}} \\
\hline & & & \\
\hline \multicolumn{4}{|c|}{$\begin{array}{l}\text { Please rate your business unit, relative to your major competitors in terms of its marketing capabilities in the following } \\
\text { areas. ( } 1=« \text { Much worse than competitors» to } 7=« \text { Much better than competitors }) \text {. }\end{array}$} \\
\hline \multicolumn{2}{|c|}{ Pricing capabilities } & \multicolumn{2}{|c|}{ Marketing communication capabilities } \\
\hline PRC1 & $\begin{array}{l}\text { Using pricing skills and systems to respond } \\
\text { quickly to market changes capabilities. }\end{array}$ & MCC1 & $\begin{array}{l}\text { Developing and executing advertising programs } \\
\text { communication. }\end{array}$ \\
\hline PRC2 & Knowledge of competitors' pricing tactics. & MCC2 & $\begin{array}{l}\text { Advertising management and creative skills } \\
\text { capabilities. }\end{array}$ \\
\hline PRC3 & $\begin{array}{l}\text { Doing an adequate job of pricing } \\
\text { products/services. }\end{array}$ & MCC3 & Public relations skills. \\
\hline \multicolumn{2}{|c|}{ Product capabilities } & MCC4 & Brand image management skills and processes. \\
\hline PC1 & \multicolumn{2}{|c|}{ Ability to develop new products/services capabilities. } & Selling capabilities \\
\hline PC2 & $\begin{array}{l}\text { Developing new products/services to exploit } \\
\text { R\&D investment. }\end{array}$ & SLC1 & $\begin{array}{l}\text { Giving salespeople the training they need to be } \\
\text { useful capabilities. }\end{array}$ \\
\hline PC3 & Successfully launching new products/services. & SLC2 & Sales management planning and control systems. \\
\hline PC4 & $\begin{array}{l}\text { Ensuring that product/service development } \\
\text { efforts are responsive to customer needs. }\end{array}$ & SLC3 & Selling skills of salespeople. \\
\hline \multicolumn{2}{|c|}{ Distribution capabilities } & SLC4 & Sales management skills. \\
\hline DC1 & $\begin{array}{l}\text { Strength of relationships with distributors' } \\
\text { capabilities. }\end{array}$ & SLC5 & Providing adequate sales support to the sales force. \\
\hline \multirow{2}{*}{\begin{tabular}{|l|}
$\mathrm{DC} 2$ \\
$\mathrm{DC} 3$ \\
\end{tabular}} & Attracting and retaining the best distributors. & \multicolumn{2}{|c|}{ Marketing planning capabilities } \\
\hline & Adding value to our distributors' businesses. & MPC1 & Marketing planning skills capabilities. \\
\hline \multirow[t]{3}{*}{ DC4 } & \multirow{3}{*}{$\begin{array}{l}\text { Providing high levels of service support to } \\
\text { distributors. }\end{array}$} & MPC2 & Ability to effectively segment and target market. \\
\hline & & MPC3 & Developing creative marketing strategies. \\
\hline & & |MPC4 & of mark \\
\hline \multirow[t]{2}{*}{$\mathrm{MIC1}$} & & MIC3 & Executing marketing strategies quickly. \\
\hline & & & \\
\hline MIC2 & $\begin{array}{l}\text { Organizing to deliver marketing programs } \\
\text { effectively capabilities. }\end{array}$ & MIC4 & Translating marketing strategies into action. \\
\hline
\end{tabular}


D. L. Florea, C. C. Munteanu, G. Capatina. The Impact of Product Category Lifecycle and Marketing Capabilities on New Product Performance: the Mediating Role of Marketing Program Planning and Launch Proficiency

Continued Table 1

Marketing program planning

Please indicate the extent to which each statement characterizes your organization on 7-point scales by pointing their level of agreement/disagreement ( $1=$ «Strongly Disagree» to $7=«$ Strongly Agree»).

Formal planning

\begin{tabular}{l|l} 
FP1 & This organization places a priority on developing written
\end{tabular} marketing plans.

FP3 Our marketing planning procedures are very formal.

\begin{tabular}{|l|l|}
\hline FP2 & When developing marketing plans, we prepare a written document that serves as a guide for making
\end{tabular} operational marketing decisions.

Strategic clarity

\begin{tabular}{|l|l|l|l|l|}
\hline SC1 & We understand the strengths and weaknesses of our marketing & SC3 & We follow through on our
\end{tabular} program. marketing strategies.

SC2 We have a clear sense of our marketing program's distinctive competencies and critical weaknesses.

Extent of segmentation

\begin{tabular}{|l|l}
\hline ES1 & This firm's products and marketing programs are targeted to
\end{tabular} identifiably unique segments.

ES3 Our firm doesn't target its products to specific customer groups. (R)

ES2 We divide our market into meaningful groups of buyers that merit separate attention.

Rapid market response

\begin{tabular}{l|l} 
RMR1 & We don't implement our marketing strategies as quickly as we should. $(\mathrm{R})$
\end{tabular}

\begin{tabular}{l|l}
\hline RMR2 & We allow marketing program ideas to sit for too long a period before acting on them. $(\mathrm{R})$
\end{tabular}

Launch proficiency

The following activities are frequently part of a new product development process. During the development of the original product that you selected, how well was each of the following activities undertaken? $(1=$ «done very poorly or mistakenly omitted altogether» to $7=$ «done excellently»)

Proficiency in market testing

\begin{tabular}{|l|l|l|l} 
PMT1 Selecting customers for testing market acceptance. & PLB1 & Determining advertising
\end{tabular}

PMT2 $\quad$ Submitting the product to customers for in-use testing. expenditures.

PMT3 Submitting the product to employees for in-use testing.

PMT4 Submitting the marketing program to customers for testing.

PMT5 Interpreting results from the market testing program.

Proficiency in launch strategy

Proficiency in launch lactics

PLS1 Segmenting the market.

PLS2 $\quad$ Selecting target customer groups.

PLT2 Determining the new product's price.

PLS3 3 Selecting the new product's positioning.

PLT3 Designing the marketing communication mix.

PLS4 Determining launch objectives.

PLS5 $\quad$ Formulating the growth strategy.

PLS6 Establishing standards to judge the new product's PLT4 Designing product mix.

performance and market acceptance.

New product performance

Please use the following scale to indicate your extent of agreement about how well the original product you selected has performed on each of the performance indicators mentioned below. (1= «very poor» to $7=$ «very good»)

Market-level measures

\begin{tabular}{|l|l|l|l|}
\hline MLM1 & Unit volume goals. & MLM3 & Met sales growth goals.
\end{tabular}

\begin{tabular}{|l|l|l|l|}
\hline MLM2 & Met revenue goals. & MLM4 & Met market share goals.
\end{tabular}

Financial measures

\begin{tabular}{|l|l|l|l}
\hline FM1 & ROI or IRR. & FM3 & Met contribution margin goals. \\
\hline
\end{tabular}

\begin{tabular}{|l|l|l|l|}
\hline FM2 & Met profitability goals. & FM4 & Development costs. \\
\hline
\end{tabular} 
D. L. Florea, C. C. Munteanu, G. Capatina. The Impact of Product Category Lifecycle and Marketing Capabilities on New Product Performance: the Mediating Role of Marketing Program Planning and Launch Proficiency

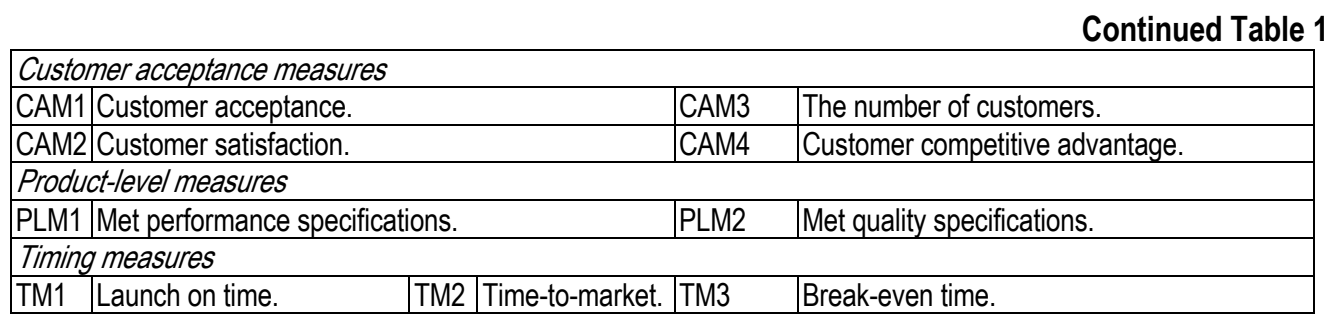

Source: Developed by the authors

For all these constructs, subjective measures were employed, given that objective data regarding the firm's internal aspects is unfeasible to obtain and that subjective measures have been proven to reveal the essence of reality in previous studies (Dess \& Robinson, 1984). Based on the work of Morgan et al. (2009), marketing capabilities were conceptualized as comprising seven types of abilities: pricing, product, distribution, marketing communication, selling, marketing planning and marketing implementation. Each of these capabilities was measured on a four-item or five-item Likert scale. Launch proficiency and new product performance were measured using the items developed and utilised by Langerak et al. (2004), while marketing program planning used the measures proposed by Conant and White (1999). All these constructs were measured on seven-point multi-item Likert scales. We used a two-stage approach to develop the measures for product category lifecycle (Langerak et al., 2004), due to unsuitable alternatives. First, to choose between formative and reflective measurement, we interviewed five academics, and we generated a pool of potentially suitable items accordingly. In the second stage, we performed cognitive interviews with five marketing practitioners to choose the best item combination, to refine complex expressions, and to discriminate between the product category lifecycle construct and other related constructs. The entire pretesting process was finished when no more issues were reported for the final version of our measures. A seven-point semantic differential scale was employed for measuring this construct. Before assessing our hypotheses, we need to ensure that our findings are based on valid and reliable data. Given that our model comprises reflective and formative measures, we need to distinguish between the two types of tests used when performing the validation of empirical data. For the constructs with reflective measures, we established convergent validity and internal consistency through exploratory factor analysis, where all the factor loadings were more significant than .70, (Carmines \& Zeller, 1979) and confirmatory factor analysis, which provided AVEs superior to the .50 benchmark (Fornell \& Larcker, 1981). Therefore, the results from both the exploratory factor analysis and confirmatory factor analysis meet the most conservative thresholds (Chin, 1998). The discriminant validity was suggested by the absence of any cross-loadings at a .40 difference or less. It was confirmed by comparing the square root of AVE with the inter-construct correlations for every latent variable (Table 2).

Table 2. Correlations between reflective constructs

\begin{tabular}{|l|c|c|c|c|c|}
\hline \multicolumn{1}{|c|}{ Variables } & $\mathbf{1}$ & $\mathbf{2}$ & $\mathbf{3}$ & $\mathbf{4}$ & $\mathbf{5}$ \\
\hline Product category lifecycle & .926 & & & & \\
\hline Formal planning & .078 & .960 & & & \\
\hline Strategic clarity & -.015 & .809 & .882 & & \\
\hline Extent of segmentation & .075 & .735 & .618 & .921 & \\
\hline Rapid market response & -.194 & .577 & .643 & .430 & .975 \\
\hline Note: The bold numbers on the diagonal are the square roots of AVE, off-diagonal numbers represent inter- \\
construct correlations \\
Source: developed by the authors.
\end{tabular}
?


D. L. Florea, C. C. Munteanu, G. Capatina. The Impact of Product Category Lifecycle and Marketing Capabilities on New Product Performance: the Mediating Role of Marketing Program Planning and Launch Proficiency

Composite reliability was analysed by comparing it with the .80 baseline proposed by Nunnally (1978), all our reflective constructs showing excellent safety. For the formatively measured constructs, we aligned to the work of Diamantopoulos et al. (2008), who state that the validity and reliability concepts do not apply to formative scales. Thus, for measure selection, we compiled a census of components for every construct, to achieve a holistic representation (Bollen \& Lennox, 1991). Multicollinearity is a significant issue when using formative measurement because the observed variables are related to the construct through multiple regression. Variance inflation factors (VIF) were calculated for every observed variable inside the constructs. Here, we meet the more liberal threshold of 10 (Hair et al., 2011) to argue that intra-construct items are sufficiently non-collinear. The sole exception of this reasoning was FM1, which has a VIF of 15.101. Because removing the item purely based on statistical results may affect the construct essence in a wrong manner (Bollen \& Lennox, 1991; Diamantopoulos et al., 2008), we performed a conceptual analysis of the situation (Diamantopoulos \& Winckhofer, 2001). Financial literature provides substantial support for profitability, profit margins and costs as ROI predictors (Altshuler \& Magni, 2015; Phillips, 1997). Therefore, our result is theoretically grounded. Consequently, removing FM1 can be considered a positive purification of the construct, given the theoretical and empirical redundancy of the item. In the measurement of first-order formative constructs, knowledge of competitors' pricing tactics (weight= .621) and price effectiveness (weight= .561) contributed most to pricing capabilities. In the formation of product capabilities, exploiting R\&D investment (weight= .725) and successfully launching new products (weight= .709) proved the most important. Service support to distributors (weight= .648) had the most prominent contribution in measuring distribution capabilities (Table 3, for the other constructs).

Table 3. Measurement model results

\begin{tabular}{|l|l|l|l|l|l|l|l|}
\hline \multicolumn{1}{|c|}{ Construct/ Dimension/ Indicator } & Mean & SD & VIF & Weight & Loading & CR & AVE \\
\hline Product category lifecycle * & & & & & & .947 & .857 \\
\hline CLC1 & 3.883 & 1.346 & & & .861 & & \\
\hline CLC2 & 3.986 & 1.358 & & & .988 & & \\
\hline CLC3 & 3.967 & 1.392 & & & .924 & & \\
\hline Marketing capabilities ** & & & & & & N.A. & N.A. \\
\hline Pricing capabilities ${ }^{* *}$ & & & & .135 & & N.A. & N.A. \\
\hline PRC1 & 5.160 & 1.196 & 3.554 & -.081 & & & \\
\hline PRC2 & 4.765 & 1.318 & 2.820 & .621 & & & \\
\hline PRC3 & 5.385 & 1.264 & 4.467 & .561 & & & \\
\hline PRC4 & 4.972 & 1.450 & 3.841 & -.010 & & & \\
\hline Product capabilities ** & & & & .078 & & N.A. & N.A. \\
\hline PC1 & 5.953 & 1.158 & 6.479 & -.256 & & & \\
\hline PC2 & 5.423 & 1.431 & 2.992 & .725 & & & \\
\hline PC3 & 5.906 & 1.226 & 9.000 & .709 & & & \\
\hline PC4 & 6.061 & 1.139 & 4.973 & .427 & & & \\
\hline Distribution capabilities ${ }^{* * 1}$ & & & & .173 & & N.A. & N.A. \\
\hline DC1 & 5.775 & 1.295 & 7.703 & -.535 & & & \\
\hline DC2 & 5.634 & 1.335 & 6.834 & .352 & & & \\
\hline DC3 & 5.700 & 1.375 & 4.093 & .562 & & & \\
\hline DC4 & 5.493 & 1.534 & 4.570 & .648 & & & \\
\hline Marketing communication capabilities ${ }^{* *}$ & & & & .172 & & N.A. & N.A. \\
\hline MCC1 & 5.441 & 1.080 & 5.413 & .502 & & & \\
\hline MCC2 & 5.371 & 1.210 & 5.325 & .175 & & & \\
\hline MCC3 & 5.070 & 1.271 & 2.194 & .170 & & & \\
\hline MCC4 & 5.761 & 1.208 & 3.082 & .243 & & & \\
\hline
\end{tabular}


D. L. Florea, C. C. Munteanu, G. Capatina. The Impact of Product Category Lifecycle and Marketing Capabilities on New Product Performance: the Mediating Role of Marketing Program Planning and Launch Proficiency

\begin{tabular}{|c|c|c|c|c|c|c|c|}
\hline \multicolumn{8}{|c|}{ Continued Table 3} \\
\hline Selling capabilities ** & & & & .207 & & N.A. & N.A. \\
\hline SLC1 & 5.873 & 1.078 & 6.771 & .547 & & & \\
\hline SLC2 & 5.962 & 1.178 & 9.259 & .250 & & & \\
\hline SLC3 & 5.380 & 1.347 & 6.317 & -.198 & & & \\
\hline SLC4 & 5.714 & 1.376 & 8.640 & -.253 & & & \\
\hline SLC5 & 5.817 & 1.498 & 4.498 & .656 & & & \\
\hline Marketing planning capabilities ${ }^{* *}$ & & & & .223 & & N.A. & N.A. \\
\hline$\overline{\mathrm{MPC1}}$ & 5.009 & 1.229 & 8.863 & .586 & & & \\
\hline MPC2 & 5.075 & 1.250 & 7.661 & -.068 & & & \\
\hline MPC3 & 4.981 & 1.571 & 2.452 & .265 & & & \\
\hline MPC4 & 4.831 & 1.544 & 6.215 & .280 & & & \\
\hline Marketing implementation capabilities ${ }^{* *}$ & & & & .194 & & N.A. & N.A. \\
\hline $\mathrm{MIC1}$ & 5.606 & 1.254 & 6.836 & .523 & & & \\
\hline MIC2 & 5.681 & 1.260 & 4.247 & -.473 & & & \\
\hline MIC3 & 4.967 & 1.764 & 4.676 & .456 & & & \\
\hline MIC4 & 5.615 & 1.395 & 2.095 & .533 & & & \\
\hline Marketing program planning ${ }^{\star \star *}$ & & & & & & N.A. & N.A. \\
\hline Formal planning * & & & & .496 & & .972 & .922 \\
\hline FP1 & 4.643 & 1.958 & & & .756 & & \\
\hline FP2 & 4.629 & 1.957 & & & .757 & & \\
\hline FP3 & 4.460 & 1.857 & & & .730 & & \\
\hline Strategic clarity* & & & & .331 & & .913 & .777 \\
\hline SC1 & 5.404 & 1.478 & & & .826 & & \\
\hline $\mathrm{SC2}$ & 5.559 & 1.402 & & & .868 & & \\
\hline SC3 & 5.263 & 1.835 & & & .794 & & \\
\hline The extent of segmentation * & & & & .144 & & .943 & .848 \\
\hline ES1 & 5.103 & 1.526 & & & .897 & & \\
\hline ES2 & 5.122 & 1.468 & & & .923 & & \\
\hline ES3 & 5.202 & 1.593 & & & .877 & & \\
\hline Rapid market response* & & & & .193 & & .974 & .950 \\
\hline RMR1 & 5.362 & 1.439 & & & .899 & & \\
\hline RMR2 & 5.413 & 1.446 & & & .890 & & \\
\hline Launch proficiency ${ }^{* * *}$ & & & & & & N.A. & N.A. \\
\hline Proficiency in market testing ** & & & & .198 & & N.A. & N.A. \\
\hline PMT1 & 5.169 & 1.781 & 8.206 & .257 & & & \\
\hline PMT2 & 5.056 & 1.820 & 6.663 & -.045 & & & \\
\hline PMT3 & 5.103 & 1.612 & 1.298 & -.163 & & & \\
\hline PMT4 & 4.371 & 1.874 & 4.804 & .471 & & & \\
\hline PMT5 & 5.305 & 1.848 & 4.136 & .441 & & & \\
\hline Proficiency in launch budgeting ** & & & & .262 & & N.A. & N.A. \\
\hline PLB1 & 5.221 & 1.436 & 5.680 & .698 & & & \\
\hline PLB2 & 5.399 & 1.518 & 4.940 & -.012 & & & \\
\hline PLB3 & 5.343 & 1.607 & 8.294 & .037 & & & \\
\hline PLB4 & 5.526 & 1.506 & 9.810 & .305 & & & \\
\hline Proficiency in launch strategy ${ }^{* *}$ & & & & .344 & & N.A. & N.A. \\
\hline PLS1 & 5.235 & 1.619 & 4.447 & .441 & & & \\
\hline PLS2 & 5.380 & 1.529 & 6.817 & $\begin{array}{l}.102 \\
\end{array}$ & & & \\
\hline PLS3 & 5.756 & 1.376 & 6.683 & .193 & & & \\
\hline PLS4 & 5.897 & 1.349 & 3.501 & .155 & & & \\
\hline
\end{tabular}


D. L. Florea, C. C. Munteanu, G. Capatina. The Impact of Product Category Lifecycle and Marketing Capabilities on New Product Performance: the Mediating Role of Marketing Program Planning and Launch Proficiency

\begin{tabular}{|c|c|c|c|c|c|c|}
\hline & & & & & \multicolumn{2}{|c|}{ Continued Table } \\
\hline PLS5 & 5.094 & 1.514 & 3.189 & -.041 & & \\
\hline PLS6 & 5.488 & 1.362 & 3.834 & .232 & & \\
\hline Proficiency in launch tactics ** & & & & .267 & N.A. & N.A. \\
\hline PLT1 & 5.685 & 1.384 & 3.005 & .335 & & \\
\hline PLT2 & 5.230 & 1.463 & 5.801 & .115 & & \\
\hline PLT3 & 5.305 & 1.543 & 5.597 & .270 & & \\
\hline PLT4 & 6.000 & 1.332 & 2.580 & .168 & & \\
\hline PLT5 & 5.615 & 1.530 & 4.490 & .226 & & \\
\hline New product performance $* * *$ & & & & & N.A. & N.A. \\
\hline Market-level measures ** & & & & .298 & N.A. & N.A. \\
\hline MLM1 & 4.765 & 1.489 & 5.313 & .419 & & \\
\hline MLM2 & 4.831 & 1.529 & 8.649 & .317 & & \\
\hline MLM3 & 4.563 & 1.613 & 8.887 & .013 & & \\
\hline MLM4 & 4.695 & 1.564 & 7.060 & .274 & & \\
\hline Financial measures ** & & & & .221 & N.A. & N.A. \\
\hline FM1 & 4.685 & 1.479 & 15.101 & .084 & & \\
\hline FM2 & 4.718 & 1.576 & 9.497 & .247 & & \\
\hline FM3 & 4.615 & 1.520 & 7.334 & .659 & & \\
\hline FM4 & 4.319 & 1.593 & 2.079 & .027 & & \\
\hline Customer acceptance measures ${ }^{* *}$ & & & & .308 & N.A. & N.A. \\
\hline CAM1 & 5.113 & 1.516 & 5.206 & .215 & & \\
\hline CAM2 & 5.563 & 1.275 & 2.553 & .018 & & \\
\hline CAM3 & 4.789 & 1.612 & 4.837 & .470 & & \\
\hline CAM4 & 5.394 & 1.543 & 3.524 & .362 & & \\
\hline Product-leve/ measures ** & & & & .098 & N.A. & N.A. \\
\hline PLM1 & 6.207 & & 3.356 & .168 & & \\
\hline PLM2 & 6.108 & & 6.406 & .743 & & \\
\hline Timing measures ** & & & & .124 & N.A. & N.A. \\
\hline TM1 & 6.047 & 1.121 & 3.098 & .085 & & \\
\hline TM2 & 6.108 & 1.093 & 3.635 & -.176 & & \\
\hline TM3 & 4.596 & 1.713 & 1.358 & .754 & & \\
\hline
\end{tabular}

Note: ${ }^{*}$ - first-order reflective construct, ${ }^{* *}-$ first-order formative construct, ${ }^{* * *}-$ second-order formative construct.

Source: developed by the authors.

For the second-order constructs, marketing planning capabilities (weight $=.223$ ) and selling capabilities (weight $=.207$ ) were the most important for the measurement of marketing capabilities. In measuring marketing program planning, formal planning (weight= .497) was the most salient aspect, followed by strategic clarity (weight= .331). Proficiency in launch strategy (weight= .344) stood out in measuring launch proficiency, while customer acceptance measures (weight $=.308$ ) stood out for new product performance.

Finally, we mention that our study adopts the molar model approach, as interrelations between firstorder constructs are not considered, being treated instead as formative dimensions of the second-order constructs (Chin \& Gopal, 1995). The calculation of second-order constructs was done by using the repeated indicator approach (Lowry \& Gaskin, 2014). Provided that our model comprises second-order factors that are simultaneously endogenous and formative, it needs to use latent variable scores as indicators for the second-order constructs as we pass to the structural model, to overcome the correctly predicted problem (Jarvis et al., 2003). 
D. L. Florea, C. C. Munteanu, G. Capatina. The Impact of Product Category Lifecycle and Marketing Capabilities on New Product Performance: the Mediating Role of Marketing Program Planning and Launch Proficiency

Results. The proposed partial least square structural equation modelling (PLS-SEM) used to test instead of covariance-based SEM (see Lowry \& Gaskin, 2014) for a comprehensive comparison between the two techniques.

Table 4 summarizes our findings by showing the standardized structural coefficients with the respective t-values using 1000 bootstrap subsamples and their corresponding hypothesis support. Results show that product category lifecycle has a significant relationship with marketing program planning ( $\beta=$ $.130, p<.01)$, in support of $\mathrm{H} 1$. In contrast, marketing capabilities positively link to product category lifecycle $(\beta=.895, p<.01)$ providing a robust empiric ground for $\mathrm{H} 6$. These two exogenous variables explain $78.3 \%$ of the variance in marketing program planning.

Table 4. Structural model results

\begin{tabular}{|c|c|c|c|}
\hline Path & $\begin{array}{c}\text { Path } \\
\text { coefficient }(\boldsymbol{\beta})\end{array}$ & $\begin{array}{c}\text { t-Value } \\
\text { (Bootstrap) }\end{array}$ & $\begin{array}{c}\text { Hypothesis } \\
\text { support }\end{array}$ \\
\hline Product category lifecycle $\rightarrow$ Marketing program planning & .130 & $3.776^{* *}$ & Yes (H1) \\
\hline Product category lifecycle $\rightarrow$ Launch proficiency & .083 & $2.369^{* *}$ & Yes (H4) \\
\hline Marketing capabilities $\rightarrow$ Marketing program planning & .395 & $3.575^{* *}$ & Yes (H6) \\
\hline Marketing capabilities $\rightarrow$ Launch proficiency & .389 & $3.412^{* *}$ & Yes (H8) \\
\hline Product category lifecycle $\rightarrow$ New product performance & .263 & $2.975^{* *}$ & Yes (H2) \\
\hline Marketing capabilities $\rightarrow$ New product performance & .365 & $3.281^{* *}$ & Yes (H7) \\
\hline Marketing program planning $\rightarrow$ New product performance & .482 & $2.876^{*}$ & Yes (H3) \\
\hline Launch proficiency $\rightarrow$ New product performance & .701 & $4.377^{* *}$ & Yes (H5) \\
\hline \multicolumn{4}{|c|}{ Controls: } \\
\hline Annual sales $\rightarrow$ New product performance & -.063 & $2.903^{* *}$ & N.A. \\
\hline Market type $\rightarrow$ New product performance & .100 & $2.032^{*}$ & N.A. \\
\hline${ }^{*}$ p $<.05 ;{ }^{* *} p<.01$ \\
\hline
\end{tabular}

Source: developed by the authors.

Product category lifecycle and marketing capabilities account for an explained variance of $77.6 \%$ in launch proficiency. In support for $\mathrm{H} 4$, product category lifecycle has a weak, but the significant link with launch proficiency $(\beta=.083, p<.01)$. Marketing capabilities prove to be actively and positively related to launching proficiency $(\beta=.889, p<.01)$, consistent with $\mathrm{H} 8$.

Product category lifecycle $(\beta=.263, p<.01)$ and marketing capabilities $(\beta=.365, p<.05)$ relate to new product performance, in support for $\mathrm{H} 2$ and $\mathrm{H} 7$, respectively. In turn, marketing program planning $(\beta=.482$, $p<.01)$ and launch proficiency $(\beta=.701, p<.05)$ also link to new product performance, in support for $\mathrm{H} 3$ and $\mathrm{H} 5$, respectively. Together with the control variables, all these variables explain $40.7 \%$ of the observed variance in new product performance.

Concerning the control variables, annual sales have a surprisingly negative link - although marginal in size - to new product performance $((\beta=-.063, p<.01)$. The market type positively affects new product performance $((\beta=.100, p<.05)$, in the sense that firms dominantly operating on business-to-consumer markets report lower performance of their new products in comparison to business-to-business firms.

Following Baron and Kenny's (1986) and MacKinnon et al. (1995)'s recommendations to calculate the direct path coefficient and the two indirect path coefficients to test the mediation roles. While SmartPLS3 does not distinguish between different indirect paths in the calculation of indirect effects when multiple mediators are considered, we performed a Sobel z-test to identify the significance of the mediated relationships. The results in Table 5 show that all the indirect paths are significant. However, the mediator of the relationship between product category lifecycle and new product performance barely reaches the significance threshold. Considering that all the direct paths were previously proved significant, we are dealing with partial mediations in all these cases, supporting thus $\mathrm{Ha}, \mathrm{Hb}, \mathrm{Hc}$, and $\mathrm{Hd}$. 
D. L. Florea, C. C. Munteanu, G. Capatina. The Impact of Product Category Lifecycle and Marketing Capabilities on New Product Performance: the Mediating Role of Marketing Program Planning and Launch Proficiency

Table 5. Mediated effects

\begin{tabular}{|l|c|c|c|c|c|}
\hline \multicolumn{1}{|c|}{ Path } & $\begin{array}{c}\text { Indirect } \\
\text { effect }\end{array}$ & $\begin{array}{c}\text { Sobel } \\
\text { test }\end{array}$ & p-value & Conclusion & $\begin{array}{c}\text { Hypothesis } \\
\text { support }\end{array}$ \\
\hline $\begin{array}{l}\text { Product category lifecycle } \rightarrow \text { Market program } \\
\text { planning } \rightarrow \text { New product performance }\end{array}$ & .062 & 2.23 & .025 & $\begin{array}{c}\text { Partial } \\
\text { mediation }\end{array}$ & Yes (Ha) \\
\hline $\begin{array}{l}\text { Product category lifecycle } \rightarrow \text { Launch proficiency } \rightarrow \\
\text { New product performance }\end{array}$ & .058 & 2.07 & .042 & $\begin{array}{c}\text { Partial } \\
\text { mediation }\end{array}$ & Yes (Hb) \\
\hline $\begin{array}{l}\text { Marketing capabilities } \rightarrow \text { Market program planning } \\
\rightarrow \text { New product performance }\end{array}$ & .190 & 2.24 & .025 & $\begin{array}{c}\text { Partial } \\
\text { mediation }\end{array}$ & Yes (Hc) \\
\hline $\begin{array}{l}\text { Marketing capabilities } \rightarrow \text { Launch proficiency } \rightarrow \text { New } \\
\text { product performance }\end{array}$ & .272 & 2.69 & .007 & $\begin{array}{c}\text { Partial } \\
\text { mediation }\end{array}$ & Yes (Hd) \\
\hline
\end{tabular}

Source: developed by the authors.

An interaction moderation analysis was performed using the product indicator calculation method (Hair et al., 2017) to assess H9. Results show that product category lifecycle strengthens the positive relationship between marketing program planning and new product performance (see Figure 2), in support of $\mathrm{H} 9$.

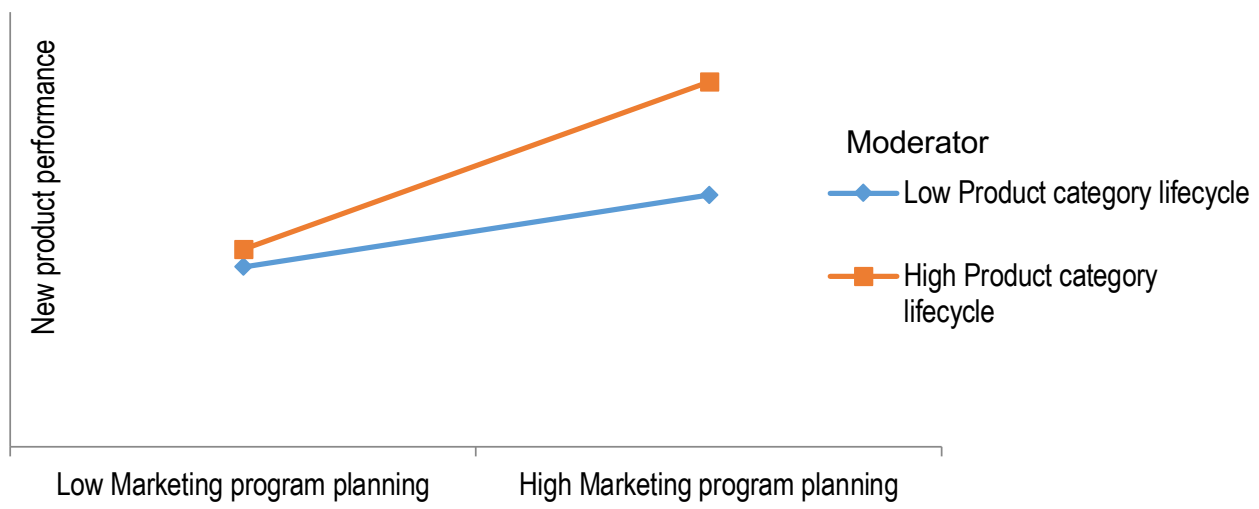

Figure 2. New product performance: interaction between marketing program planning and product category lifecycle

Source: developed by the authors.

The empirical findings support all hypotheses and show that product category lifecycle and marketing capabilities affect new product performance both directly and through mediators as marketing program planning or launch proficiency. In supporting hypothesis $\mathrm{H} 1$, we reinforce the resource-advantage theory (Hunt, 1997), by providing strong empirical evidence for the role of organizational learning in the context of category lifecycle progress. The confirmation of $\mathrm{H} 2$ merges a wide range of conclusions from previous studies concerning the relationship between different indicators of category lifecycle and new product performance. Thus, new products reach better results when introduced at more advanced stages of their product category lifecycle. The findings in respect to $\mathrm{H} 3$ align with the part of literature that endorses the relationship between marketing program planning and new product performance (Conant \& White, 1999; Brinckmann et al., 2010). By finding strong empirical support for $\mathrm{H} 4$, we manage to confirm from another perspective Agarwal and Audretsch's (2001) conclusion that launch proficiency increases as the product category matures. The validation of $\mathrm{H} 5$ demonstrates that new product performance is positively 
influenced by a high level of proficiency in overall product launch activities affects, in contrast to Langerak et al. (2004), who find support only for launch tactics, or other studies that include only certain aspects of launch proficiency (Song \& Parry, 1996).

To the best of our knowledge, the support of $\mathrm{H} 6$ represents the first empirical confirmation of the link between marketing capabilities and marketing program planning. It shows that developing the capabilities of the marketing department will improve the process of marketing planning. Also, capable marketing departments and managers have a clear strategic vision. Finally, a formal plan should not be treated as the company's choice, but more as an indicator of its marketing capabilities. Our work provides additional evidence to the connection between marketing capabilities and new product performance by supporting $\mathrm{H7}$, in line with most of the marketing literature (O'Cass \& Heirati, 2015; Ngo \& O'Cass, 2012; Langerak et al., 2004). Also, in line with previous research (Ngo \& O'Cass, 2012), $\mathrm{H} 8$ is supported, providing one of the most reliable available evidence for the relationship between marketing capabilities and launch proficiency. The moderating role of the product category lifecycle hypothesized in $\mathrm{H} 9$ can be regarded as counterintuitive. Still, a strong empirical support to complement Bowman and Gatignon's (1996) conclusions on the moderating effect of order-of-entry in the relationship between marketing mix and market share.

Beyond the support for our hypotheses, the strength of the effects studied in the current paper presents much interest for marketing scholars and management. Of the two exogenous variables, marketing capabilities have the most positive direct and indirect impact on new product performance. At the level of the total effect, product category lifecycle has less than half of the impact that marketing capabilities exert on new product performance. Specifically, the total effect of product category lifecycle on new product performance is .383, compared with .827 for marketing capabilities. This result endorses the importance of marketing capabilities development in the process of introducing new products in comparison with the lower significance of the product category lifecycle. The strategic marketing orientation regarding new products becomes crucial to the overall performance of the original product along its lifecycle.

The study confirms the importance of the product launch strategy and its implementation as a critical factor for new product performance. The firm's proficiency in new product introduction proved far more impactful on new product performance than the overall marketing planning, which leaves its mark throughout the product's existence. In other words, depending on its launch success, a new product can be either blessed or doomed, because it is difficult to recover from a «false start» or an early failure. Despite these gloomy perspectives for new products - caused by a high uncertainty in demand - we demonstrate that a strong customer orientation can be particularly useful when marketing a new product. It must be noted that this conclusion is valid only if the marketing strategy associated with the latest product is carefully planned and implemented. The study provides arguments against blaming the product category lifecycle for the failure of new products. Despite having a significant impact on new product performance, the effect of product category lifecycle is inferior to the firms' marketing capabilities. Thus, such managerial behaviour is trying to hide marketing-related failures by highlighting an uncontrollable factor, but with marginal effects for new product success. We believe that strong marketing knowledge and excellent strategic clarity will lead to superior performance in any scenario. It is especially true for a new product scenario, because, in this case, proper marketing program planning will not necessarily lead to better or improved products but will lead to certain products that perform better in the marketplace.

In the same line, the current stage of the product category lifecycle should not be used to justify launch procrastination or launch cancellation. While indeed leaving the launch for a more advanced stage in the product category lifecycle can provide a solid ground for better marketing planning, a more proficient marketing department in launch activities can lead to better performance indicators for the new product. It must be noted that all these benefits can be obtained more efficiently if the firm develops the capabilities of its marketing department instead of relying on service externalization. This implication supports Day's 

Product Performance: the Mediating Role of Marketing Program Planning and Launch Proficiency

(2011) critics of linking launch recommendations to industry lifecycle or the "five competitive forces» model. Moreover, waiting for advancement in the product lifecycle stage is not a valid option considering its rather unforeseeable evolution. Therefore, adopting a comprehensive approach which includes developing a technology competence driven by R\&D and a market knowledge competence driven by a sharp but concise marketing approach can considerably increase the success rates of new products.

While the low success rate of new product launches may suggest some real hardships that are uncontrollable and difficult to adapt to, our study instead places the fault on the marketing manager's shoulders. Despite the unfavourable stage in the category lifecycle, the new product can achieve reasonably good sales figures if a company with strong marketing capabilities supports it.

The study provides evidence for the importance of a successful product launch for the prospective performance of the new product on a short-term and mid-term horizon. While nothing can be said concerning long-term performance, as we did not measure it in our study, it is clear that a failed launch can not be reverted entirely on a mid-term. Therefore, managers should pay special attention to the planning and implementation of new product launches as a critical moment for the firm's survival. As a direct consequence, we emphasize that companies simply cannot afford to fail in adopting a strong marketing orientation. We actively recommend a competitive adjustment centred around marketing innovations when demand is not highly uncertain or when competing in a growing market. In contrast, we thoroughly recommend a competitive orientation focused on R\&D to discover «the next big thing» when demand is highly uncertain or when competing in a declining market.

The moderating effect of product category lifecycle - proven in the study - attributes managers with more accountability for improving strategic clarity, strategic formality and the segmentation process. Also, our results emphasize the need for proactivity in marketing planning when dealing with advanced stages of the product category lifecycle, because this is the most critical period in regards to new product performance. Traditionally, the advanced stages of the product category lifecycle are seen as painful periods for a new product launch, given the lack of market potential and the time needed to reach the break-even point. Finally, the study also demonstrates that launch proficiency is more important for new product performance than marketing program planning. As a result, activities directly related to the original product launch have a more significant impact on the overall business of the firm compared to the general strategic vision.

Conclusions. This paper brings two significant contributions to the existing scientific literature regarding new product development and launch. By different product category lifecycle and marketing capabilities, we demonstrate the prevalence of internal factors for the success of the new product, filling thus the literature gap created by conjoint studies regarding internal and external determinants. We also contrast launch proficiency against marketing program planning to strengthen the importance of a successful launch process for the later performance of the new product.

The study reanalyses the product lifecycle, one of the most meaningful and intuitive concepts in marketing science, after a period of neglect in scholars' scientific interests. The novelty in our approach consists in treating the product lifecycle as an uncontrollable and mostly unpredictable variable, rather than as an available decision when launching a new product (Rink \& Swan, 1979).

While our study contains several limitations, they also create avenues for future research. First, although multiple industries were included in our sample for more generalizable findings, our hypotheses need further testing based on more diverse samples, extracted from different countries. Secondly, to obtain reliable data, our sample included firms that reportedly launched a new product in the past 24 months before the interview. Future research should additionally consider new products started a more extended time ago, which will enable the study of long-term product performance. Thirdly, the indirect effects account only for $31 \%$ of the total impact on the case of product category lifecycle and for $55 \%$ in the case of marketing capabilities, which leaves the chance to find additional mediators of their influence 
D. L. Florea, C. C. Munteanu, G. Capatina. The Impact of Product Category Lifecycle and Marketing Capabilities on New Product Performance: the Mediating Role of Marketing Program Planning and Launch Proficiency

on new product performance. Finally, other potential determinants of new product performance from the internal and external environment should be considered to challenge the main conclusion, to clarify the balance between the external and internal factors that influence new product performance, and to reach higher levels of explained variance in the endogenous variable.

Author Contributions: The authors contributed as following: conceptualization, D. F. and C. M.; methodology, D. F., C. M. and D. G.; software, D. F. and D. G.; validation, D. F., C. M. and G. C.; formal analysis, D. F. and C. M; investigation, D. F. and D. G.; resources, D. F. and D. G.; data curation, D. G.; writing-original draft preparation, D. F., C. M., D. G., and G. C.; writing-review and editing, D. F., C. M., D. G., and G. C.; visualization, D. G.; supervision, D. F.; project administration, D. F.; funding acquisition, D. F and D. G.

\section{References}

Agarwal, R., \& Audretsch, D.B. (2001). Does entry size matter? The impact of the life cycle and technology on firm survival The Journal of Industrial Economics, 49(1), 21-43. [Google Scholar] [CrossRef]

Agarwal, R., Sarkar, M.B., \& Echambadi, R. (2002). The conditioning effect of time on firm survival: An industry life cycle approach. Academy of Management Journal, 45(5), 971-994. [Google Scholar] [CrossRef]

Altshuler, D., \& Magni, C.A. (2015). Introducing Aggregate Return on Investment as a Solution to the contradiction between some PME metrics and IRR. Journal of Performance Measurement, 20(1), 48-56. [Google Scholar] [CrossRef]

Armstrong, J.S., \& Overton, T.S. (1977). Estimating nonresponse bias in mail surveys. Journal of Marketing Research, 14(3), 396-402. [Google Scholar] [CrossRef]

Atuahene-Gima, K. (2005). Resolving the capability-rigidity paradox in new product innovation. Journal of marketing, 69(4), 6183. [Google Scholar] [CrossRef]

Baker, W.E., Sinkula, J.M., Grinstein, A., \& Rosenzweig, S. (2014). The effect of radical innovation in/congruence on new product performance. Industrial Marketing Management, 43(8), 1314-1323. [Google Scholar] [CrossRef]

Baron, R.M., \& Kenny, D.A. (1986). The moderator-mediator variable distinction in social psychological research: Conceptual, strategic, and statistical considerations. Journal of personality and social psychology, 51(6), 1173. [Google Scholar] [CrossRef]

Bello, D.C., Radulovich, L.P., Javalgi, R.R.G., Scherer, R.F., \& Taylor, J. (2016). Performance of professional service firms from emerging markets: Role of innovative services and firm capabilities. Journal of World Business, 51(3), 413-424. [Google Scholar] [CrossRef]

Bingham, C.B., Eisenhardt, K.M., \& Furr, N.R. (2007). What makes a process a capability? Heuristics, strategy and effective capture of opportunities. Strategic Entrepreneurship Journal, 1(1-2), 27-47. [Google Scholar] [CrossRef]

Bollen, K., \& Lennox, R. (1991). Conventional wisdom on measurement: A structural equation perspective. Psychological bulletin, 110(2), 305. [Google Scholar] [CrossRef]

Bowman, D., \& Gatignon, H. (1996). Order of entry as a moderator of the effect of the marketing mix on market share. Marketing Science, 15(3), 222-242. [Google Scholar] [CrossRef]

Brinckmann, J., Grichnik, D., \& Kapsa, D. (2010). Should entrepreneurs plan or just storm the castle? A meta-analysis of contextual factors impacting the business planning-performance relationship in small firms. Journal of Business Venturing, 25(1), 24-40. [Google Scholar] [CrossRef]

Cacciolatti, L., \& Lee S.H. (2016). Revisiting the relationship between marketing capabilities and firm performance: The moderating role of market orientation, marketing strategy and organizational power. Journal of Business Research, 69(12), 55975610. [Google Scholar] [CrossRef]

Calantone, R.J., \& Di Benedetto, C. A. (2012). The role of lean launch execution and launch timing on new product performance. Journal of the academy of marketing science, 40(4), 526-538. [Google Scholar] [CrossRef]

Calantone, R.J., Yeniyurt, S., Townsend, J.D., \& Schmidt, J.B. (2010). The effects of competition in short product life-cycle markets: The case of Motion Picture. Journal of Product Innovation Management, 27(3), 349-361. [Google Scholar] [CrossRef]

Carmines, E.G., \& Zeller, R.A. (1979). Reliability and validity assessment (Vol. 17). Sage Publications. [Google Scholar]

Cassar, G. (2014). Industry and startup experience on entrepreneur forecast performance in new firms. Journal of Business Venturing, 29(1), 137-151. [Google Scholar] [CrossRef]

Castellion, G., \& Markham, S.K. (2013). Perspective: New Product Failure Rates: Influence of Argumentum ad P opulum and Self-Interest. Journal of Product Innovation Management, 30(5), 976-979. [Google Scholar] [CrossRef]

Cavusgil, E., Deligonul, Z.S., \& Calantone, R. (2011). Late entrant over-the-counter and Rx market entry strategies. International Journal of Pharmaceutical and Healthcare Marketing. [Google Scholar] [CrossRef]

Child, J. (1997). Strategic choice in the analysis of action, structure, organization and environment: Retrospect and prospect. Organization Studies, 18(1), 43-76. [Google Scholar] [CrossRef] 
D. L. Florea, C. C. Munteanu, G. Capatina. The Impact of Product Category Lifecycle and Marketing Capabilities on New Product Performance: the Mediating Role of Marketing Program Planning and Launch Proficiency

Chin, W.W., \& Gopal, A. (1995). Adoption intention in GSS: relative importance of beliefs. DATABASE for Advances in information Systems, 26(2-3), 42-64. [Google Scholar] [CrossRef]

Conant, J.S., \& White, J.C. (1999). Marketing program planning, process benefits, and store performance: an initial study among small retail firms. Journal of Retailing, 75(4), 525-541. [Goole Scholar] [CrossRef]

Cooper, R.G. (2011). Perspective: The innovation dilemma: How to innovate when the market is mature. Journal of Product Innovation Management, 28(s1), 2-27. [Google Scholar] [CrossRef]

Cooper, R.G. (1984). New product strategies: what distinguishes the top performers? Journal of Product Innovation Management, 1(3), 151-64. [Google Scholar] [CrossRef]

Day, G.S. (2011). Closing the marketing capabilities gap. Journal of Marketing, 75(4), 183-195. [Google Scholar] [CrossRef

Dess, G.G., \& Robinson Jr, R.B. (1984). Measuring organizational performance in the absence of objective measures: the case of the privately-held firm and conglomerate business unit. Strategic management Journal, 5(3), 265-273. [Google Scholar] [CrossRef Diamantopoulos, A., Riefler, P., \& Roth, K.P. (2008). Advancing formative measurement models. Journal of business research, 61(12), 1203-1218. [Google Scholar] [CrossRef]

Diamantopoulos, A., \& Winckhofer, H.M. (2001). Index construction with formative indicators: An alternative to scale development. Journal of marketing research, 38(2), 269-277. [Google Scholar] [CrossRef]

Dibrell, C., Craig, J.B., \& Neubaum D.O. (2014). Linking the formal strategic planning process, planning flexibility, and innovativeness to firm performance. Journal of Business Research, 67(9), 2000-2007. [Google Scholar] [CrossRef] Ernst, H., \& Fischer, M. (2014). Integrating the R\&D and Patent Function: Implication for New Product Performance. Journal of Product Innovation Management, 31, 118-132. [Google Scholar] [CrossRef]

Fornell, C., \& Larcker, D.F. (1981). Evaluating structural equation models with unobservable variables and measurement errors. Journal of marketing research, 18(1), 39-50. [Google Scholar] [CrossRef]

Gatignon, H., Gotteland, D., \& Haon, C. (2016). Making innovation last: Volume 2: Sustainable strategies for long term growth. Springer. [Google Scholar]

Gatignon, H., \& Robertson, T.S. (1985). A propositional inventory for new diffusion research. Journal of consumer reesearch, 11(4), 849-867. [Google Scholar] CrossRef]]

Gatignon, H., \& Xuereb, J.M. (1997). Strategic orientation of the firm and new product performance. Journal of marketing research, 34(1), 77-90. [Google Scholar] [CrossRef]

Gourville, J.T. (2006). Eager sellers and stony buyers: Understanding the psychology of new-product adoption. Harvard business review, 84(6), 98-106. [Google Scholar]

Green, D.H., Barclay, D.W., \& Ryans, A.B. (1995). Entry strategy and long-term performance: Conceptualization and empirical examination. Journal of marketing, 59(4) 1-16. [Google Scholar] [CrossRef]

Hair, J.F., Hult, G.T.M., Ringle, C.M, \& Sarstedt, M. (2017). A primer on partial least squares structural equation modeling (PLS$S E M)$. (2nd ed). Thousand Oaks: Sage.

Hair, J.F., Ringle, C.M., \& Sarstedt, M. (2011). PLS-SEM: Indeed a silver bullet. Journal of Marketing theory and Practice, 19(2),

139-152. [Google Scholar] [CrossRef]

Heirati, N., \& O'Cass, A. (2016). Supporting new product commercialization through managerial social ties and market knowledge development in an emerging economy. Asia Pacific Journal of Management, 33(2), 411-433. [Google Scholar] [CrossRef] Henard, D.H., \& Szymanski, D.M. (2001). Why some new products are more successful than others. Journal of marketing Research, 38(3), 362-375. [Google Scholar] [CrossRef]

Huang, C.T., \& Tsai, K.H. (2014). Synergy, environmental context, and new product performance: A review based on manufacturing firms. Industrial Marketing Management, 43(8), 1407-1419. [Google Scholar] [CrossRef]

Hulland, J., Baumgartner, H., \& Smith, K.M. (2018). Marketing survey research best practices: evidence and recommendations from a review of JAMS articles. Journal of the Academy of Marketing Science, 46(1), 92-108. [Google Scholar] [CrossRef] Hunt, S. D., \& Morgan, R.M. (1996). The resource-advantage theory of competition: dynamics, path dependencies, and evolutionary dimensions. Journal of marketing, 60(4), 107-114. [Google Scholar] [CrossRef]

Hunt, S. D., \& Morgan, R.M. (1997). Resource-advantage theory: a snake swallowing its tail or a general theory of competition? Journal of Marketing, 61(4), 74-82. [Google Scholar] [CrossRef]

Jain, D. (2001). Managing new-product development for strategic competitive advantage. In lacobucci, D. (ed.), Kellogg on Marketing, New York: Wiley.

Jarvis, C.B., MacKenzie, S.B., \& Podsakoff, P.M. (2003). A critical review of construct indicators and measurement model misspecification in marketing and consumer research. Journal of consumer research, 30(2), 199-218. [Google Scholar] [CrossRef] Ketchen, D., \& Hult, G.T.M. (2011). Marketing and organization theory: opportunities for synergy. Journal of the Academy of Marketing Science, 39(5), 1-3. [Google Scholar] [CrossRef]

Kim, N., Shin, S., \& Min, S. (2016). Strategic marketing capability: Mobilizing technological resources for new product advantage. Journal of Business Research, 6(12), 5644-5652. [Google Scholar] [CrossRef]

Kraiczy, N.D., Hack, A., \& Kellermanns, F.W. (2014). New product portfolio performance in family firms. Journal of Business Research, 67(6), 1065-1073. [Google Scholar] [CrossRef]

Kuester, S., Hess, S.C., \& Herrmann, A. (2015). The role of defaults in preventing innovation rejection. International Journal of Innovation Management, 19(2), 1550023. [Google Scholar] [CrossRef] 
D. L. Florea, C. C. Munteanu, G. Capatina. The Impact of Product Category Lifecycle and Marketing Capabilities on New Product Performance: the Mediating Role of Marketing Program Planning and Launch Proficiency

Kuester, S., Homburg, C., \& Hess, S.C. (2012). Externally directed and internally directed market launch management: the role of organizational factors in influencing new product success. Journal of Product Innovation Management, 29, 38-52. [Google Scholar] [CrossRef]

Langerak, F., Hultink, E.J., \& Robben, H. S. (2004). The impact of market orientation, product advantage, and launch proficiency on new product performance and organizational performance. Journal of product innovation management, 21(2), 79-94. [Google Scholar] [CrossRef]

Lawry, P.B., \& Gaskin, J. (2014). Partial least squares (PLS) structural equation modeling (SEM) for building and testing behavioral causal theory: When to choose it and how to use it. IEEE transactions on professional communication, 57(2), 123-146. [Google Scholar] [CrossRef]

Lieberman, M.B., \& Montgomery, D.B. (2013). Conundra and progress: Research on entry order and performance. Long Range Planning, 46(4-5), 312-324. [Google Scholar] [CrossRef]

MacKinnon, D.P., Warsi, G., \& Dwyer, J.H. (1995). A simulation study of mediated effect measures. Multivariate behavioral research, 30(1), 41-62. [Google Scholar] [CrossRef]

Markides, C., \& Sosa, L. (2013). Pioneering and first mover advantages: the importance of business models. Long Range Planning, 46(4-5), 325-334. [Google Scholar] [CrossRef]

Montoya-Weiss, M.M., \& Calantone, R. (1994). Determinants of new product performance: a review and meta-analysis. Journal of Product Innovation Management: An International Publication Of The Product Development \& Management Assotiation, 11(5), 397-417. [Google Scholar] [CrossRef]

Moorman, C., \& Slotegraaf, R.J. (1999). The contingency value of complementary capabilities in product development. Journal of Marketing Research 36(2), 239-257. [Google Scholar] [CrossRef]

Morgan, N.A. (2012). Marketing and business performance. Journal of the Academy of Marketing Science, 40(1), 102-119. [Google Scholar] [CrossRef

Morgan, N.A., Vorhies, D.W., \& Mason, C.H. (2009). Market orientation, marketing capabilities, and firm performance. Strategic management journal, 30(8), 909-920. [Google Scholar] [CrossRef]

$\mathrm{Mu}$, J. (2015). Marketing capability, organizational adaptation and new product development performance. Industria/ Marketing Management, 49, 151-166. [Google Scholar] [CrossRef]

$\mathrm{Mu}$, J. (2014). Networking capability, network structure, and new product development performance. IEEE Transactions on Engineering Management, 61(4), 599-609. [Google Scholar] [CrossRef]

$\mathrm{Mu}$, J., \& Di Benedetto, C.A. (2011). Strategic orientations and new product commercialization: mediator, moderator, and interplay. R\&D Management, 41(4), 337-359. [Google Scholar] [CrossRef]

Muller-Stewens, B., \& Moller, K. (2017). Performance in new product development: a comprehensive framework, current trends, and research directions. Journal of Management Control, 28(2), 157-201. [Google Scholar] [CrossRef]

Murray, J.Y., Gao, G.Y., \& Kotabe, M. (2011). Market orientation and performance of export ventures: the process through marketing capabilities and competitive advantage. Journal of the Academy of Marketing Science, 39(2), 252-269. [Google Scholar] [CrossRef]

Najafi-Tavani, S., Sharifi, H., \& Najafi-Tavani, Z. (2016). Market orientation, marketing capability, and new product performance: The moderating role of absorptive capacity. Journal of Business Research, 69(11), 5059-5064. [Google Scholar] [CrossRef]

Narver, J.C., \& Slater S.F. (1990). The effect of a market orientation on business profitability. Journal of Marketing, 54(4), 2035. [Google Scholar] [CrossRef]

Ngo, L.V., \& O'Cass, A. (2012). In search of innovation and customer-related performance superiority: The role of market orientation, marketing capability and innovation capability interactions. Journal of Product Innovation Management, 29(5), 861-877. [Google Scholar] [CrossRef]

Nunnally, J.C. (1978). Psychometric theory 2nd Ed. New York: McGraw-Hill.

O'Cass, A. \& Heirati, N. (2015). Mastering the complementarity between marketing mix and customer-focused capabilities to enhance new product performance. Journal of Business \& Industrial Marketing. [Google Scholar] [CrossRef]

Phillips, J.J. (1997). Measuring return on investment. Alexandria: American Society for Training \& Development.

Ploscaru, C.C., Munteanu, C.C., \& Florea, D.L. (2014). The Implementation of Corporate Governance into Brand Management. SEA: Practical Application of Science, 2(3). http://seaopenresearch.eu/Journals/articles/SPAS_5_73.pdf.

Reid, S.E., Roberts, D., \& Moore, K. (2015). Technology vision for radical innovation and its impact on early success. Journal of Product Innovation Management, 43(4), 593-609. [Google Scholar] [CrossRef]

Rink, D.R., \& Swan, J.E. (1979). Product life cycle research: A literature review. Journal of Business Research, 7(3), 219-242. [Google Scholar] [CrossRef

Rodriguez-Pinto, J., Carbonell, P., \& Rodriguez-Escudero, A.I. (2011). Speed or quality? How the order of market entry influences the relationship between market orientation and new product performance. International Journal of Research in Marketing 28(2), 145-154. [Google Scholar] [CrossRef]

Rogers, E. M (1983). Diffusion of innovations. (3rd ed). New York: Free Press.

Rue, L.W., \& Ibrahim, N.A. (1998). The relationship between planning sophistication and performance in small businesses. Journal of small business management, 36(4), 24. [Google Scholar] 
D. L. Florea, C. C. Munteanu, G. Capatina. The Impact of Product Category Lifecycle and Marketing Capabilities on New Product Performance: the Mediating Role of Marketing Program Planning and Launch Proficiency

Rust, R.T., Ambler, T., Carpenter, G.S., Kumar, V., \& Srivastava, R.K. (2004). Measuring marketing productivity: Current knowledge and future directions. Journal of marketing, 68(4), 76-89. [Google Scholar] [CrossRef]

Schoenherr, T., \& Swink, M. (2015). The roles of supply chain intelligence and adaptability in new product launch success. Decision Sciences, 46(5), 901-936. [Google Scholar] [CrossRef]

Schuhmacher, M.C., Kuester, S., \& Hanker, A.L. (2018). Investigating antecedents and stage-specific effects of customer integration intensity on new product success. International Journal of Innovation Management, 22(4), 1850032. [Goole Scholar] [CrossRef]

Schuhmacher, M.C., Kuester, S., \& Hultink, E.J. (2018). Appetizer or Main Course: Early Market vs. Majority Market Go-toMarket Strategies for Radical Innovations. Journal of product innovation management, 35(1), 106-124. [Google Scholar] [CrossRef] Schwenk, C.R., \& Shrader, C.B. (1993). Effect of formal strategic planning on financial performance in small firms: A metaanalysis. Entrepreneurship: theory and practice, 17(3), 53-64. [Google Scholar] [CrossRef]

Slater, S.F., \& Narver, J.C. (1994). Does competitive environment moderate the market orientation-performance relationship? Journal of Marketing, 58(1), 46-55. [Google Scholar] [CrossRef]

Song, M., Im, S., Bij, H., \& Song, L.Z. (2011). Does strategic planning enhance of impede innovation and firm performance? Journal of Product Innovation Management, 28(4), 503-520. [Google Scholar] [CrossRef]

Song, X.M., \& Parry, M.E. (1996). What separates Japanese new product winners from losers. Journal of Product Innovation Management: An international publication of the product development \& management association, 13(5), 422-439. [Google Scholar] [CrossRef]

Story, V.M., Boso, N., \& Cadogan, J.W. (2015). The form of relationship between firm-level product innovativeness and new product performance in developed and emerging markets. Journal of Product Innovation Management, 32(1), 45-64. [Google Scholar] [CrossRef]

Su, M., \& Rao, V.R. (2011). Timing decisions of new product preannouncement and launch with competition. International Journal of Production Economics, 129(1), 51-64. [Google Scholar] [CrossRef]

Suarez, F.F., Grodal, S., \& Gotsopoulos, A. (2015). Perfect timing? Dominant category, dominant design, and the window of opportunity for firm entry. Strategic Management Journal, 36(3), 437-448. [Google Scholar] [CrossRef]

Talke, K., \& Hultink, E.J. (2010a). The impact of the corporate mind-set on new product launch strategy and market performance. Journal of Product Innovation Management, 27(2), 220-237. [Google Scholar] [CrossRef]

Talke, K., \& Hultink, E.J. (2010b). Managing diffusion barriers when launching new products. Journal of Product Innovation Management, 27 (4), 537-553. [Google Scholar] [CrossRef]

Theodosiou, M., Kehagias, J., \& Katsikea, E. (2012). Strategic orientation, marketing capabilities and firm performance: An empirical investigation in the context of frontline managers of service organizations. Industrial Marketing Management, 41(7), 10581070. [Google Scholar] [CrossRef]

Vanhaverbeke, W., Belderbos, R., Duysters, G., \& Beerkens, B. (2015). Technological performance and alliances over the industry life cycle: evidence fron the ASIC industry. Journal of Product Innovation Management, 32(4), 556-573. [Google Scholar] [CrossRef]

Varadarajan, R. (2010). Strategic marketing and marketing strategy: domain, definition, fundamental issues and foundational premises. Journal of the Academy of Marketing Science, 38(2), 119-140. [Google Scholar] [CrossRef]

Verhoef, P.C., \& Leeflang, P.S. (2009). Understanding the marketing department's influence within the firm. Journal of marketing, 73(2), 14-37. [Google Scholar] [CrossRef]

Vorhies, D.W., Orr, L.M., \& Bush, V.D. (2011). Improving customer-focused marketing capabilities and firm financial performance via marketing exploration and exploitation. Journal of the Academy of Marketing Science, 39(5), 736-756. [Google Scholar] [CrossRef]

Vickery, S.K., Koufteros, X., Droge, C., \& Calantone, R. (2016). Product modularity, process modularity, and new product introduction performance: does complexity matters? Production and Operations management, 25(4), 751-770. [Google Scholar] [CrossRef]

Vorhies, D.W., \& Morgan, N.A. (2005). Benchmarking marketing capabilities for sustained competitive advantage. Journal of marketing, 69(1), 80-94. [Google Scholar] [CrossRef]

Workman Jr, J.P. (1993). Marketing's limited role in new product development in one computer systems firm. Journal of Marketing Research, 30 (4), 405-421. [Google Scholar] [CrossRef]

Zacharias, N.A., Stock, R.M., \& Im, S. (2017). Strategic Givens in New Product Development: Understanding Curvilinear Effects on New Product Performance. International Journal of Innovation Management, 21(1), 1750010. [Google Scholar] [CrossRef]

Zahra, S.A., Criaco, G., Naldi, L., \& Larraneta, B. (2015). Industry knowledge characteristics, prior experience and new venture survival. In Academy of Management Proceedings, (Vol. 2015, No. 1, p. 17103). Briarcliff Manor, NY 10510: Academy of Management. [Google Scholar] [CrossRef 
D. L. Florea, C. C. Munteanu, G. Capatina. The Impact of Product Category Lifecycle and Marketing Capabilities on New Product Performance: the Mediating Role of Marketing Program Planning and Launch Proficiency

\begin{abstract}
Доріан-Лаурентій Флореа, Ph.D., Університет Ануак Мексика (Мексика);
Клавдіу-Каталін Мунтіяну, Ph.D., Румунська академія (Румунія);

Дора-Кармен Галвес Крус, Ph.D., Університет Ануак Мексика (Мексика),

Габріела Капатіна, Ph.D., Бухарестський університет економічних досліджень (Румунія).

Вплив життєвого циклу товару та ринкового потенціалу на випуск нового продукту: посередницька роль маркетингової програми та ефективності виходу на ринок

Згідно теоретичної концепції, основою виживання та успішного розвитку компанії $є$ постійний випуск нових продуктів. Авторами зазначено, що розвиток нового продукту залежить від керованих (зовнішніх та внутрішніх) та некерованих факторів. Метою даного дослідження $є$ пошук балансу між двома детермінантами ефективності випуску нового товару на ринок, а саме: роль життєвого циклу товару; ринковий потенціал. Для тестування моделі, основою якої є теорії ресурсних переваг та стратегічного вибору, використано структурне моделювання та метод найменших квадратів (PLS-SEM). Для дослідження сформовано вибірку з 213 мексиканських компаній. Отримані результати свідчать про те, що роль життєвого цикпу товару та ринковий потенціал $є$ статистично значущими детермінантами-впливу на успішність виведення товару на ринок. При цьому ринковий потенціал має більшу силу впливу, аніж життєвий цикл товару. Встановлено, що взаємозв'язок між ринковим потенціалом та запуском нового продукту визначається його маркетинговою програмою, тоді як взаємозв'язок між життевим циклом продукту та розвитком нового продукту - ефективністю його виведення на ринок. У свою чергу, ефективність маркетингової програми відображає середньо- та довгострокові характеристики стратегічного маркетингу, тоді як загальна ефективність виведення товару на ринок відображає короткострокову спроможність компанії запускати нові продукти. Авторами встановлено, що життєвий цикл продукту посилює позитивний взаємозв'язок між маркетинговою програмою та розвитком нового продукту. У статті наголошено, що маркетингова програма повинна адаптуватись відповідно до етапу життєвого циклу товару. Відповідно до теорії стратегічно вибору, отримані результати дослідження підкреслюють статистичну значущість успішного виведення нового товару на ринок. Авторами зазначено, що проведене дослідження не враховувало неконтрольовані ринкові фактори, що можуть спричинити зниження ефективності виведення нового товару на ринок. При цьому доведено, що головною причиною провалу нового продукту $\epsilon$ неспроможність менеджера з маркетингу розробити дієвий маркетинговий план. Дана робота вносить вклад у науковий доробок щодо теорії ресурсних переваг, надаючи емпіричне обгрунтування важливості ринкового потенціалу для успішного виведення нового товару на ринок.

Ключові слова: ефективність запуску, ринковий потенціал, маркетингове планування програми, розвиток нового продукту, життєвий цикл продукту.
\end{abstract}

Manuscript received: 17.09.2019.

(C) The author(s) 2020. This article is published with open access at Sumy State University. 